\title{
Apigenin induces caspase-dependent apoptosis in human lung cancer A549 cells through Bax- and Bcl-2-triggered mitochondrial pathway
}

\author{
HSU-FENG LU ${ }^{1,3 *}$, YU-JIE CHIE ${ }^{5 *}$, MING-SUNG YANG ${ }^{2}$, CHING-SUNG LEE ${ }^{3}$, \\ JENE-JOHN FU ${ }^{4}$, JAI-SING YANG ${ }^{6}$, TZU-WEI TAN ${ }^{6}$, SHIN-HWAR WU ${ }^{8,10}$, \\ YI-SHIH MA ${ }^{9}$, SIU-WAN IP ${ }^{7}$ and JING-GUNG CHUNG ${ }^{5,11}$
}

\begin{abstract}
Departments of ${ }^{1}$ Clinical Pathology and ${ }^{2}$ General Thoracic Surgery, Cheng Hsin General Hospital, Taipei 112;
${ }^{3}$ Department of Restaurant, Hotel and Institutional Management, Fu-Jen Catholic University, Taipei 242;

${ }^{4}$ Chief Medical Office, Landseed International Medical Group, Taoyuan 324; Departments of ${ }^{5}$ Biological Science and Technology, ${ }^{6}$ Pharmacology and ${ }^{7}$ Nutrition, ${ }^{8}$ Graduate Institute of Clinical Medical Science and ${ }^{9}$ Chinese Medical Science, China Medical University, Taichung 404; ${ }^{10}$ Division of Critical Care Medicine, Department of Internal Medicine, Changhua Christian Hosptial, Changhua 500; ${ }^{11}$ Department of Biotechnology, Asia University, Taichung 413, Taiwan, R.O.C.
\end{abstract}

Received October 5, 2009; Accepted February 26, 2010

DOI: 10.3892/ijo_00000634

\begin{abstract}
The molecular mechanism and possible signaling pathway of apigenin-induced cytotoxicity and apoptosis in human lung cancer cells has not been reported. We investigated the role of ROS, $\mathrm{Ca}^{2+}$, caspases and Bax proteins and mitochondria membrane potential in apigenin-induced apoptosis in A549 cells. Cells were incubated with different concentrations of apigenin then cell morphological changes, DNA damage, cell viability and apoptosis were determined by Comet assay, and flow cytometric analysis. Sub-G1 phase was also examined. Western blot analysis was used to determined the levels of Bax and Bcl-2 and apoptosis associated proteins, and confocal laser microscope for examining the translocation of associated protein after exposed to apigenin. The results indicated that apigenin induced morphological changes, decreased percentage of viable cells and induced apoptosis dose- and timedependently. DAPI staining and Comet assay also confirmed that apigenin-induced DNA condensation and damage. The levels of caspase-3, -8 and -9 involved in apigenin-induced apoptosis indicating caspase-dependent pathway was induced by apigenin. Western blotting showed that apigenin
\end{abstract}

Correspondence to: Dr Jing-Gung Chung, Department of Biological Science and Technology, China Medical University, no. 91, Hsueh-Shih Road, Taichung 404, Taiwan, R.O.C.

E-mail: jgchung@mail.cmu.edu.tw

*Contributed equally

Key words: apigenin, apoptosis, Bax protein, caspases, A549 lung cancer cells promoted cytochrome c levels and also induced dysfunction of mitochondria leading to the release of cytochrome $c$, AIF and Endo G, causing the activation of caspase- 9 and -3 , then apoptosis in A549 cells.

\section{Introduction}

Lung cancer continues to be a major health problem worldwide (1). In Taiwan, lung cancer is the top cause of cancer-related deaths in men and women with about 32.8 persons per 100,000 dying annually from lung cancer, based on reports from the Department of Health, Executive Yuan, R.O.C. (Taiwan) (http://www.doh.gov.tw/EN2006/index_EN.aspx.). The treatment of lung cancer includes surgery, radiotherapy and chemotherapy. However, the results are not satisfactory. Therefore, the mortality in lung cancer patients remains high. Many reports have shown naturally-occurring compounds with chemopreventive and chemotherapeutic properties (2-4). It is well known that consumption of a phytochemical-rich diet such as fruits and vegetables can decrease the risk of certain types of human cancers $(5,6)$. So far, many prescription drugs in clinical treatment of cancer patients are derived from natural plant species $(7,8)$.

Apigenin (4',5,7-trihydroxyflavone), is one of the favonoids which have been reported to be able to act as anticancer agents, and is abundantly present in common fruits and vegetables, and can also act as a chemopreventive agent $(9,10)$. In animals, apigenin can inhibit tumor initiation which is induced by various carcinogens $(11,12)$. Furthermore, apigenin has been shown to suppress angiogenesis in melanoma and carcinoma of the breast, skin, and colon (1316). It has been demonstrated that: i) apigenin sensitizes tumor cells to TNF- $\alpha$-induced apoptosis through inhibition of $\mathrm{NF}-\kappa \mathrm{B}(17)$; ii) apigenin induces apoptosis in solid tumors through up-regulation of IGFBP-3 (18); iii) apigenin-induced suppression of tumor proliferation correlates with down- 
regulation of cyclin D1 (19) and apigenin-induced prostate cancer cell death is initiated by reactive oxygen species and p53 activation (20).

It was reported that apigenin is capable of selectively inhibiting cell growth and inducing apoptosis in cancer cells without affecting normal cells (21). However, there is no report to address apigenin affecting human lung cancer cells. Herein, we investigated the cytotoxic and pro-apoptotic effects of apigenin in human lung cancer A549 cells. We also explored the role of caspases and mitochondria in apigenininduced apoptosis in A549 cells.

\section{Materials and methods}

Materials and chemicals. Apigenin, dimethyl sulfoxide (DMSO), propidium iodide (PI), trypan blue and Triton X-100 were obtained from Sigma Chemical. (St. Louis, MO, USA). The fluorescent probe for $\mathrm{ROS}, \mathrm{Ca}^{2+}$ and mitochondrial membrane potential such as 2',7'-dichlorofluorescin diacetate (DCFH-DA), Indo 1/AM and $\mathrm{DiOC}_{6}$ were from Calbiochem (La Jolla, CA, USA). All primary and secondary antibodies were obtained from Santa Cruz Biotechnology (CA, USA).

Cell culture. Human lung cancer A549 cells were obtained from the Food Industry Research and Development Institute (Hsinchu, Taiwan). Cells were plated in RPMI-1640 medium (Gibco-BRL, Grand Island, NY, USA) supplemented with 10\% FBS (Hyclone Laboratories, Logan, UT, USA), 1\% penicillin-streptomycin $(100 \mathrm{U} / \mathrm{ml}$ penicillin and $100 \mu \mathrm{g} / \mathrm{ml}$ streptomycin) and $1 \% \mathrm{~L}$-glutamine and then were cultured under a humidified $5 \% \mathrm{CO}_{2}$ and $95 \%$ air grown at $37^{\circ} \mathrm{C}$ and one atmosphere in an incubator $(21,22)$.

Determinations of cell morphology, cell viability, cell cycle and apoptosis by PI staining. A549 cells $\left(5 \times 10^{5}\right.$ cells/well $)$ were grown in 12-well plates for $24 \mathrm{~h}$ and then were treated with $0,40,60,80,120$ and $160 \mu \mathrm{M}$ apigenin and were incubated at $37^{\circ} \mathrm{C}, 5 \% \mathrm{CO}_{2}$ and $95 \%$ air for $48 \mathrm{~h}$ and then photographed under contrast pharse microscope and harvested by centrifugation. For viability determination, cells were stained with PI $(5 \mu \mathrm{g} / \mathrm{ml})$ and analyzed by flow cytometry (Becton-Dickinson, San Jose, CA, USA) as previously described (22). For cell cycle and apoptosis determinations, cells were fixed gently in $70 \%$ ethanol at $4^{\circ} \mathrm{C}$ overnight and then re-suspended in PBS containing $40 \mu \mathrm{g} / \mathrm{ml} \mathrm{PI}$ and $0.1 \mathrm{mg} / \mathrm{ml}$ RNase and $0.1 \%$ Triton X-100 in a dark room for $30 \mathrm{~min}$ at $37^{\circ} \mathrm{C}$. Cells were analyzed with a flow cytometer equipped with an argon ion laser at $488 \mathrm{~nm}$ wavelength $(21,22)$.

Determination of DNA damage by DAPI staining and Comet assay. A549 cells $\left(5 \times 10^{4}\right.$ cells $\left./ \mathrm{ml}\right)$ were treated with 40,60 , 80,120 and $160 \mu \mathrm{M}$ of apigenin for $24 \mathrm{~h}$. Cells were then stained with DAPI (4,6-diamidino-2-phenylindole dihydrochloride) and were photographed using a fluorescence microscope as previously described (22). Cells were harvested by centrifugation, isolated and examined for DNA damage by using the Comet assay as previously described $(22,23)$.

Detection of reactive oxygen species, $\mathrm{Ca}^{2+}$ levels and mitochondrial membrane potential. A549 cells were plated onto 12-well plates and treated with $120 \mu \mathrm{M}$ of apigenin for various time periods before being harvested, washed twice, and re-suspended in the ROS indicator 2,7-dichlorodihydrofluorescein diacetate $\left(\mathrm{H}_{2} \mathrm{DCF}-\mathrm{DA}\right)$, calcium probe Indo $1 / \mathrm{AM}$ and the mitochondrial membrane potential indicator 3 , 3'-dihexyloxacarbocyanine iodide $\left(\mathrm{DiOC}_{6}\right)$ and then incubated at $37^{\circ} \mathrm{C}$ for $30 \mathrm{~min}$ for flow cytometry to detect changes in $\mathrm{ROS}, \mathrm{Ca}^{2+}$ levels and mitochondrial membrane potential as previously described $(24,25)$.

Determinations of cell cycle and apoptosis associated proteins by Western blotting. A549 cells $\left(5 \times 10^{6}\right)$ were treated with $120 \mu \mathrm{M}$ apigenin for $0,6,12,24$ and $48 \mathrm{~h}$. Cells were harvested by centrifugation and the total proteins were collected and determined from each treatment. The cyclin B, cdc25c, wee 1, p53, chk2, Bid, Bax, Bcl-2, Grp78, GADD153 and GRP78 (Santa Cruz Biotechnology, CA, USA), cytochrome c, procaspase-3, procaspase-8, procaspase-9 (R\&D Systems, Minneapolis, MN, USA), AIF, Endo G (Santa Cruz Biotechnology) were measured by sodium dodecyl sulfate-polyacrylamide gel electrophoresis (SDS-PAGE) and Western blotting as described previously $(22,26)$.

Determinations of cytochrome c, AIF and Endo G locations by confocal laser scanning microscopy. A549 cells ( $5 \times 10^{4}$ cells/ well) were plated on 4-well chamber slides and were treated with $120 \mu \mathrm{g} / \mathrm{M}$ apigenin for $24 \mathrm{~h}$. Cells were fixed in $4 \%$ formaldehyde in PBS for $15 \mathrm{~min}$, permeabilized with $0.3 \%$ Triton-X 100 in PBS for $1 \mathrm{~h}$ with blocking of non-specific binding sites using $2 \%$ BSA as described previously (22). Fixed cells were stained with primary antibodies to cytochrome c, AIF and Endo G (1:100 dilution) (green fluorescence) overnight then followed by the exposure of secondary antibody (FITC-conjugated goat anti-mouse IgG at 1:100 dilution) and then stained with PI (red fluorescence). Photomicrographs were obtained using a Leica TCS SP2 Confocal Spectral Microscope (22).

Statistical analysis. Student's t-test was used to analyze differences between apigenin-treated and control groups. ${ }^{*} \mathrm{p}<0.05 ;{ }^{* *} \mathrm{p}<0.01 ;{ }^{* * *} \mathrm{p}<0.001$.

\section{Results}

Apigenin induces growth inhibition of A549 cells. A549 cells were treated with various concentrations of apigenin and we investigated the growth inhibition, the results are shown in Fig. 1A and B. Results indicated that apigenin induced morphological changes (Fig. 1A) and decreased the percentage of viable cells (Fig. 1B) and the $\mathrm{IC}_{50}$ of the apigenin was $72.1 \mu \mathrm{M}$ in A549 cells. We further investigated whether apigenin could cause cell cycle arrest in A549 cells. The flow cytometric assay indicated that apigenin induced G2/M arrest (Fig. 1C) and these effects were dose-dependent in A549 cells. Apoptotic A549 cells after apigenin treatment are shown in Fig. 1D (see also Table I).

Apigenin induced DNA damage and apoptosis in A549 cells. For investigating apigenin induced apoptosis via DNA 
A
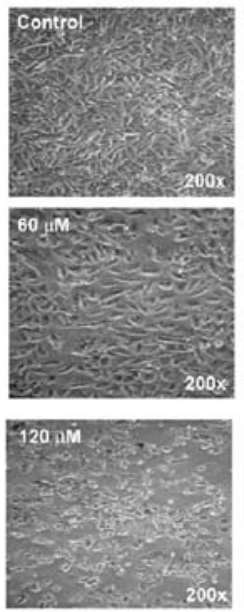
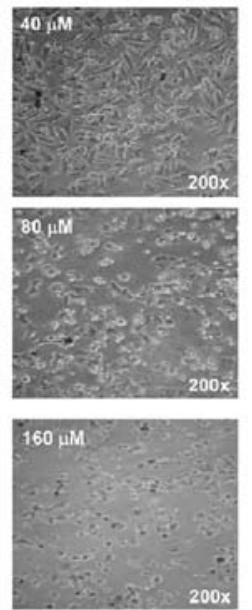

B

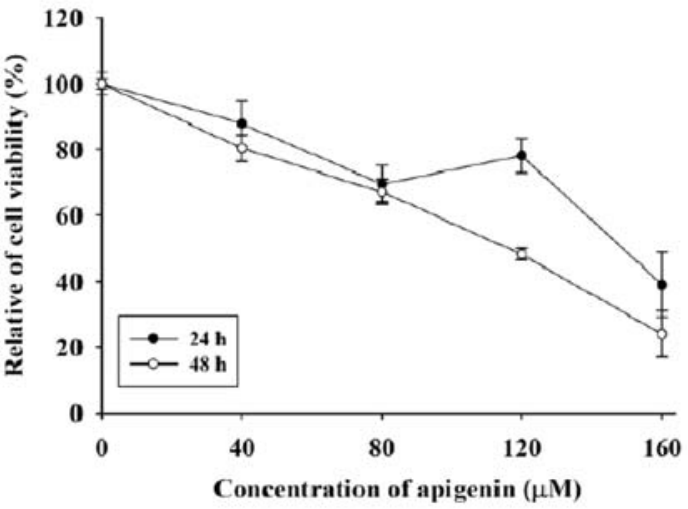

D

C

C
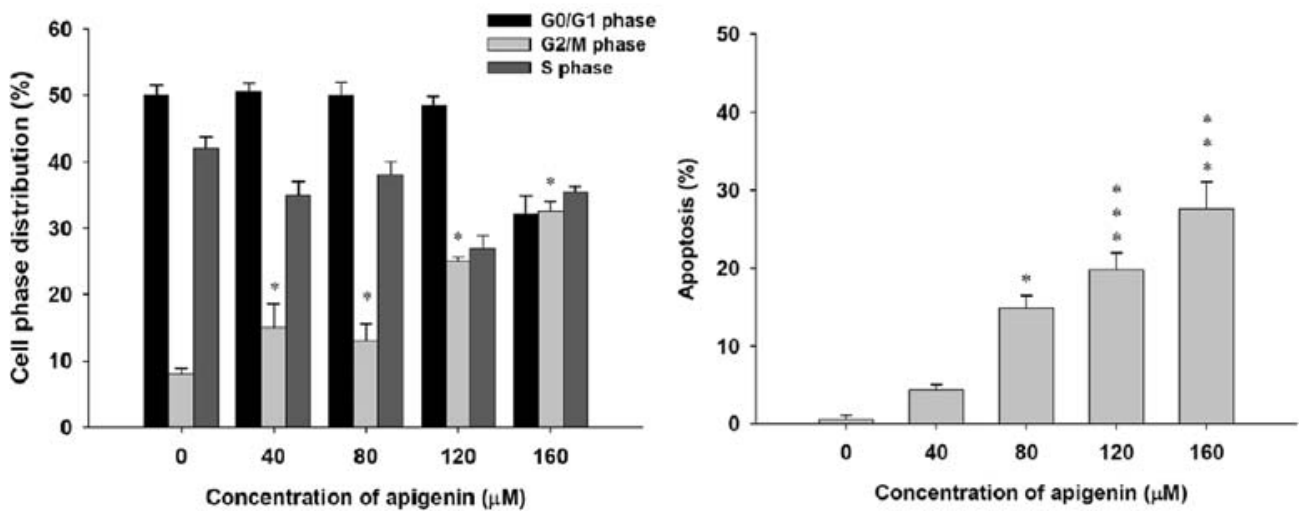

Figure 1. Growth inhibition of apigenin on A549 cells. Cells were treated with various concentrations of apigenin before examining the growth inhibition including the metrological changes (A) which were examined under a microscope, photographed and the percentage of viable A549 cells (B) and cell cycle distribution (C) and apoptotic A549 cells (D) were determine by flow cytometric analysis as described in Materials and methods.

Table I. Flow cytometric analysis of apoptotic cell death in human lung cancer A549 cells with or without apigenin treatment.

Concentration $(\mu \mathrm{M})$

Apoptosis (\% of total cells)

$\begin{array}{rc}0 & 0.6 \pm 0.4 \\ 40 & 4.4 \pm 0.7 \\ 80 & 14.9 \pm 1.6^{\mathrm{a}} \\ 120 & 19.8 \pm 2.2^{\mathrm{b}} \\ 160 & 27.6 \pm 3.5^{\mathrm{b}}\end{array}$

Values are mean $\pm \mathrm{SD}, \mathrm{n}=3$. The A549 cells $\left(2 \times 10^{5}\right.$ cells $\left./ \mathrm{ml}\right)$ were exposed to various concentrations of apigenin. The percentage of total apoptotic cells were determined by flow cytometry as described in Materials and methods. Differs between apigenin and control. ${ }^{\mathrm{a}} \mathrm{p}<0.05 ;{ }^{\mathrm{b}} \mathrm{p}<0.001$.

damage, the A549 cells were treated with apigenin, then isolated for DAPI staining and Comet assay. The results indicated that apigenin induced DNA condensation (Fig. 2A) and fluorescence intensity (Fig. 2B) and DNA damage (Fig. 2C) and increased Comet tail (Fig. 2D). These effects were dose-dependent.

Apigenin promotes reactive oxygen species and $\mathrm{Ca}^{2+}$ production and induces loss of mitochondrial membrane potential $\left(\Delta \Psi_{m}\right)$ in A549 cells. For investigating apigenin induced DNA damage and whether or not it occurs via the production of ROS and $\mathrm{Ca}^{2+}$, the cells were treated with apigenin for various time periods. A549 cells were harvested for examining the ROS and $\mathrm{Ca}^{2+}$ productions and the levels of $\Delta \Psi_{\mathrm{m}}$. Fig. 3 indicates that apigenin promoted the levels of ROS (Fig. 3A) and $\mathrm{Ca}^{2+}$ (Fig. 3B) but decreased the levels of $\Delta \Psi_{\mathrm{m}}$ (Fig. 3C) in A549 cells. These effects were timedependent.

Apigenin induces apoptosis in A549 cells through the effects associated protein levels. For investigating the possible signaling pathways for apigenin induced apoptosis in A549 cells, A549 cells were treated with $150 \mu \mathrm{M}$ of apigenin for 0 , $6,12,24,48$ and $72 \mathrm{~h}$ before cells were collected for analysis of the protein level changes by Western blotting. The results indicated that apigenin increased wee 1, p53 and chk2 (Fig. 4A), Bid, Bax, Grp78 and GADD153 (Fig. 4B), AIF, 
A
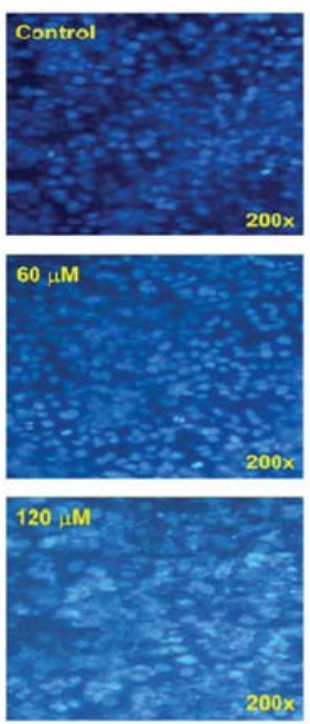

C
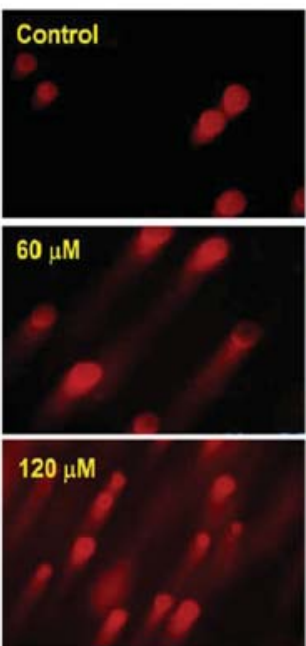
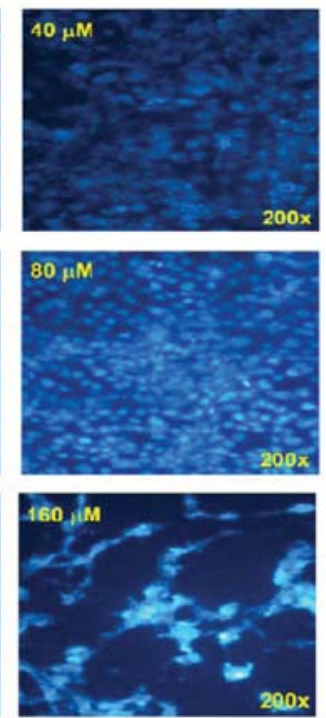

\section{D}
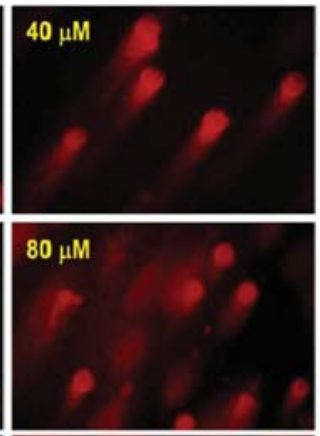

$160 \mu \mathrm{M}$

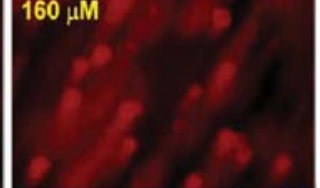

B
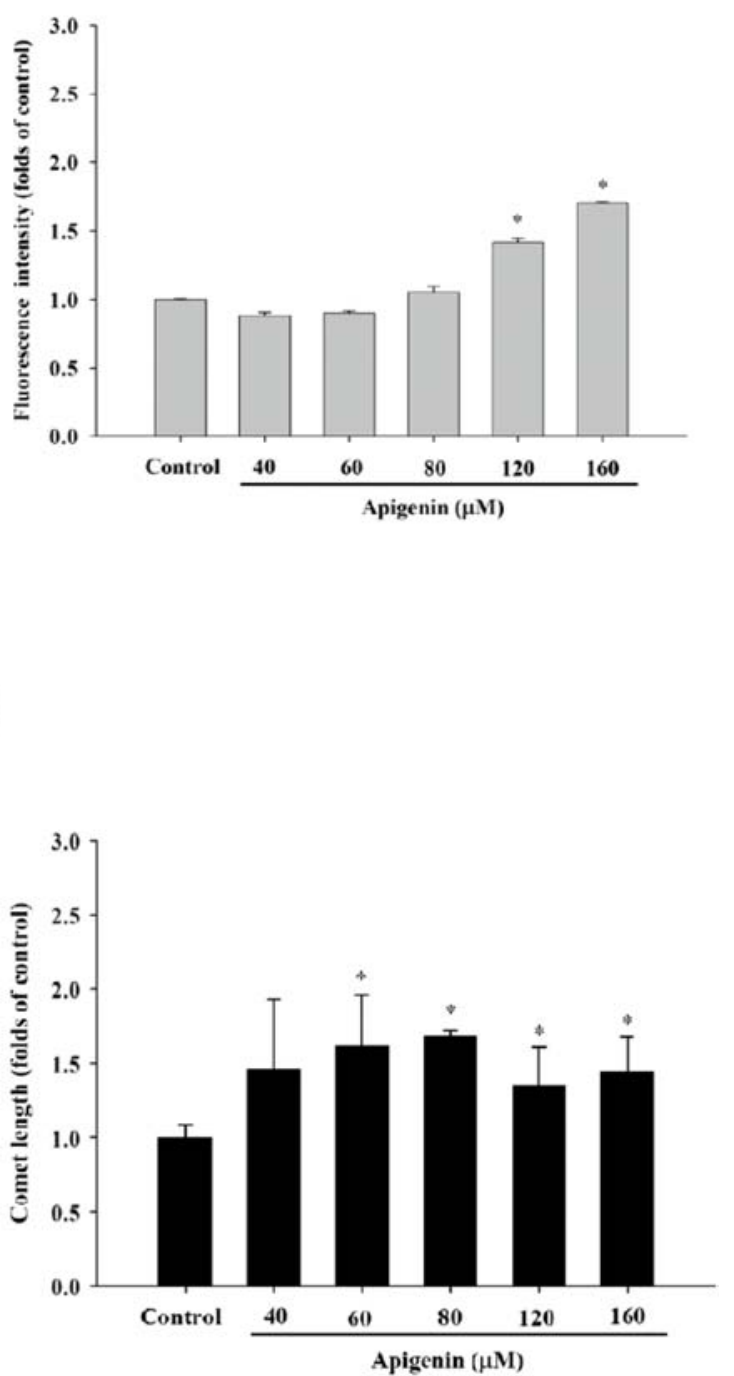

Figure 2. Apigenin-induced apoptosis and DNA damage in A549 cells. Cells were treated with various concentrations of apigenin for 24 h and then isolated for DAPI staining (A) and quantitative fluorescence intensity (B), Comet assay (C) and quantitative Comet tail (D) as described in Materials and methods.

cytochrome c (Fig. 4C), but decreased the levels of cyclin B and cdc25c (Fig. 4A), Bcl-2 (Fig. 4B), procaspase-9, -3 and -8 and PARP (Fig. 4C) protein levels in A549 cells. We suggest that apigenin-induced apoptosis is mediated through mitochondrial and caspase- $8,-9$ and -3 pathways.

Apigenin affects apoptosis-associated protein translocation in A549 cells. A549 cells (5x104 cells/well) plated on 4-well chamber slides were treated with $120 \mu \mathrm{g} / \mathrm{ml}$ apigenin for $24 \mathrm{~h}$ then were stained by antibody and examined and photographed by confocal laser microscopy. The results indicated that AIF (Fig. 5A), Endo G (Fig. 5B) and GADD153 (Fig. 5C) are released from mitochondria then translocated to the nuclei.

\section{Discussion}

In this study, we demonstrated that apigenin is able to induce apoptosis in human lung cancer A549 cells in vitro.
Induction of apoptosis is accompanied by increases in ROS and $\mathrm{Ca}^{2+}$ production, promoted Bax level and inhibited Bcl-2 level for changing the ratio of $\mathrm{Bax} / \mathrm{Bcl}-2$, before leading to loss of mitochondrial membrane potential $\left(\Delta \Psi_{\mathrm{m}}\right)$, causing cytochrome c, AIF and Endo G release from mitochondria and promote caspase-9 and -3 activation as shown in Fig. 6. Other studies have been shown that apigenin-induced p53-dependent apoptosis occurs in prostate cancer $(17,19)$. Numerous studies have shown that apigenin can suppress the growth of malignant prostate cells and tumor xenografts in vivo through cell cycle arrest and induction of apoptosis (17-19). We also observed apigenin-induced DNA damage and p53 expression and this is in agreement with other reports which demonstrated that the p53-associated pathway is required for apigenin-mediated apoptosis, as evidenced by the p53 antisense oligo-nucleotide experiment (27).

Results showed that apigenin increased ROS production in the earlier time periods of treatment and ROS were 
A

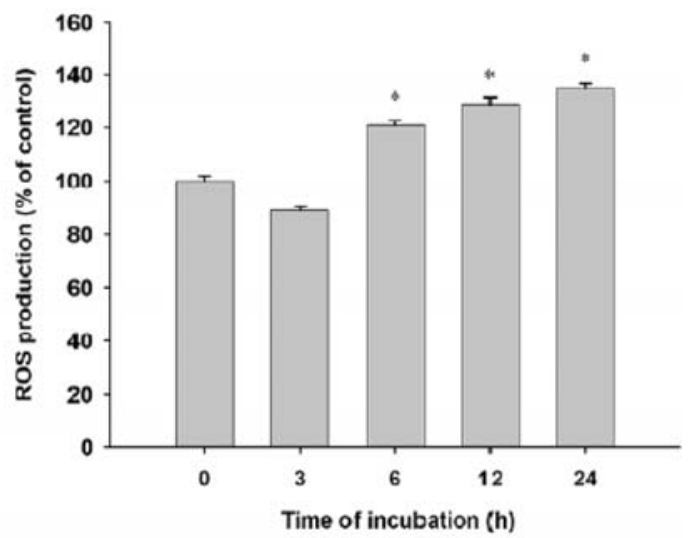

B

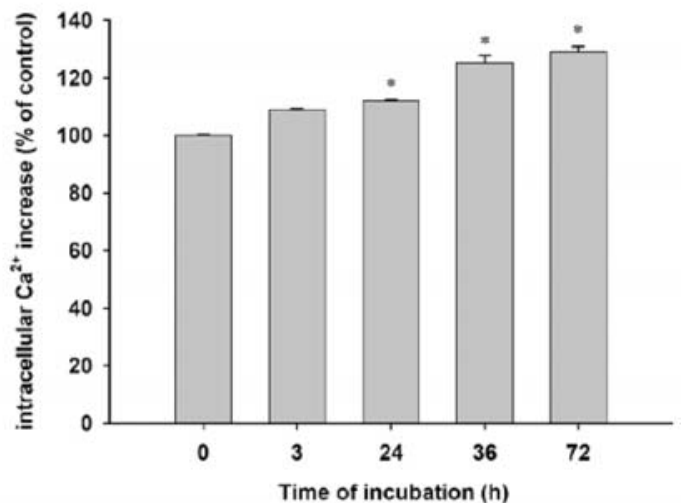

C

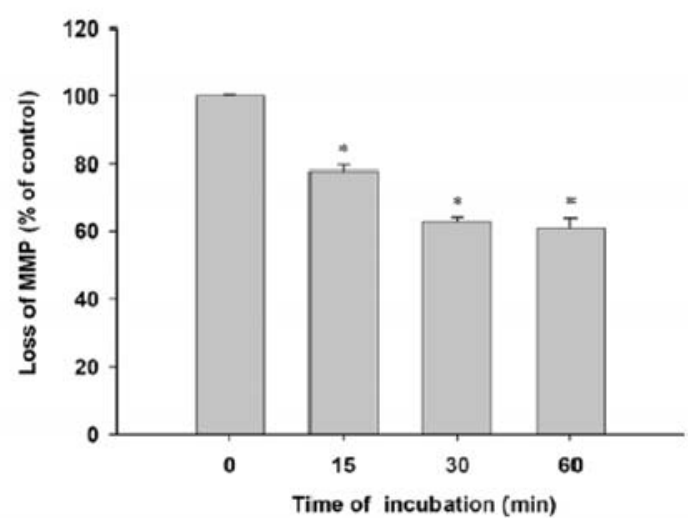

Figure 3. Apigenin induces ROS and $\mathrm{Ca}^{2+}$ production and loss of $\Delta \Psi_{m}$ in A549 cells. Cells were treated with various concentrations of apigenin for different time periods, and the cells were harvested for examining the ROS (A) and $\mathrm{Ca}^{2+}(\mathrm{B})$ production and the levels of $\Delta \Psi_{m}(\mathrm{C})$ as described in Materials and methods.

associated with apigenin-induced DNA damage based on Comet assay (Fig. 2C and D). Substantial evidence suggest a role for ROS in apoptosis induced by agents including certain chemopreventive agents, through the engagement of downstream proteins involved in the execution of apoptosis (28-30).

It is recognized that the intracellular generation of $\mathrm{H}_{2} \mathrm{O}_{2}$ (the most stable ROS) was an important mediator of apoptosis including exogenous addition of $\mathrm{H}_{2} \mathrm{O}_{2}$ that is a potent activator of the apoptotic machinery (31) and some of the added $\mathrm{H}_{2} \mathrm{O}_{2}$ diffuses into the mitochondria and perhaps causes damage to the mitochondrial membrane $(22,31)$. Another factor is that
A

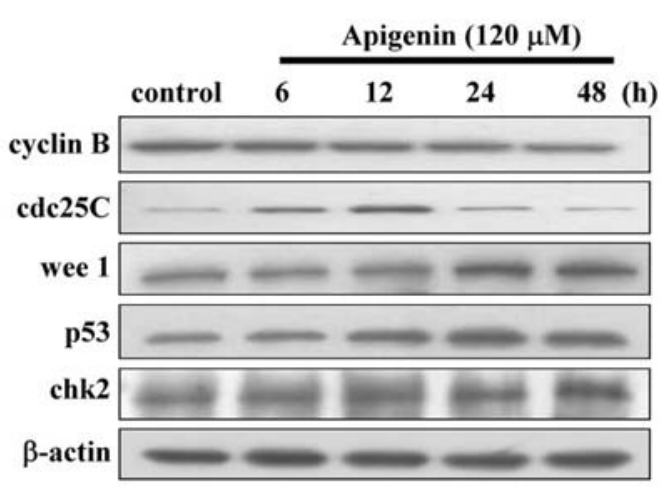

B

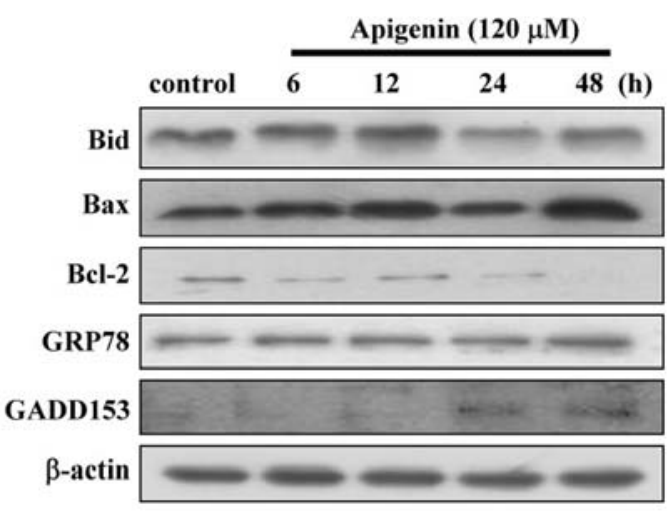

C

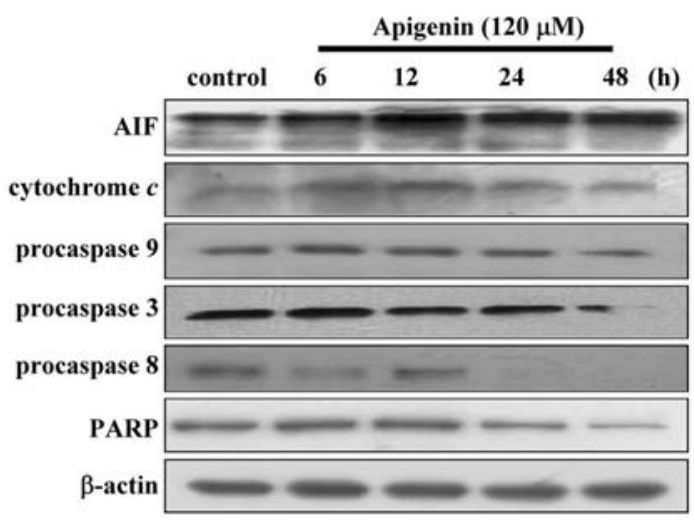

Figure 4. Apigenin affects apoptosis-associated proteins in A549 cells. Cells were treated with $120 \mu \mathrm{M}$ of apigenin $6,12,24$ and $48 \mathrm{~h}$, and the cells were harvested for examining the associated protein levels (A, cyclin B, cdc25c, wee 1, p53 and chk2; B, Bid, Bax, Bcl-2, GRP78 and GADD153; C, AIF, cytochrome c, procaspase- $9,-3$ and -8, PARP) as described in Materials and methods.

mitochondrially produced $\mathrm{H}_{2} \mathrm{O}_{2}$ diffuses into the cytosol where it may exert cytotoxic effects.

Our results also showed that apigenin decreased the levels of $\Delta \Psi_{\mathrm{m}}$ in A549 cells (Fig. 3C). It is well known that mitochondria can act in execution of apoptosis and mitochondria and also play an essential role in death signal transduction by the permeability transition pore opening and collapse of the $\Delta \Psi_{\mathrm{m}}$, resulting in the rapid release cyto-chrome $\mathrm{c}$ into the cytoplasm before binding to Apaf- 1 and activating caspase- 3 via caspase-9, culminating in cell death $(32,33)$, and AIF or Endo $\mathrm{G}$ release from mitochondria into the nuclei for causing apoptosis (34). Fig. 5 shows that apigenin induced AIF and 
A

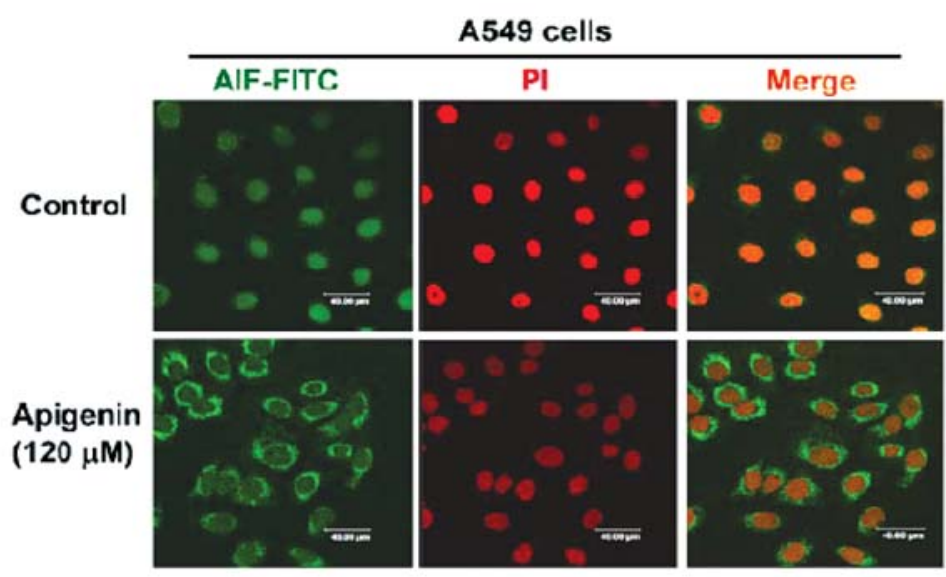

B

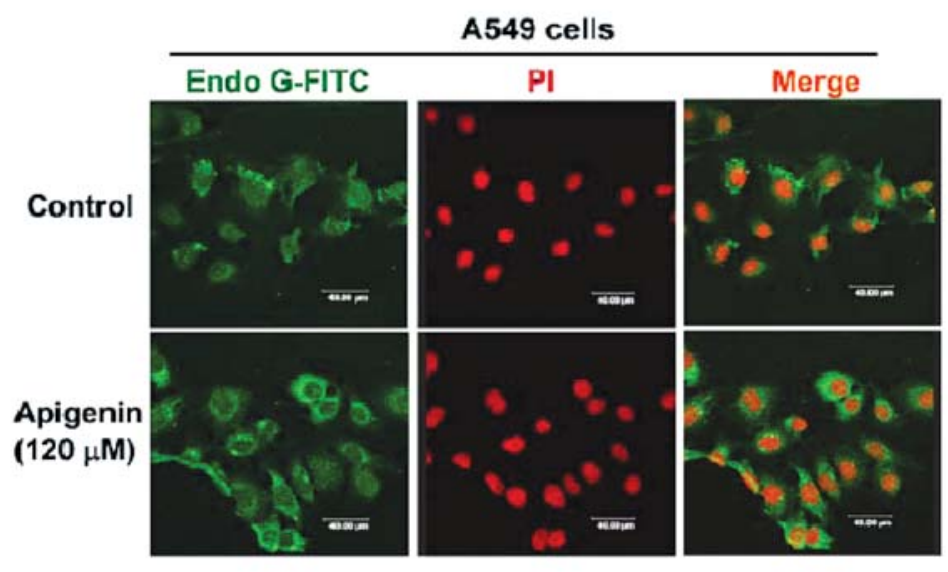

C

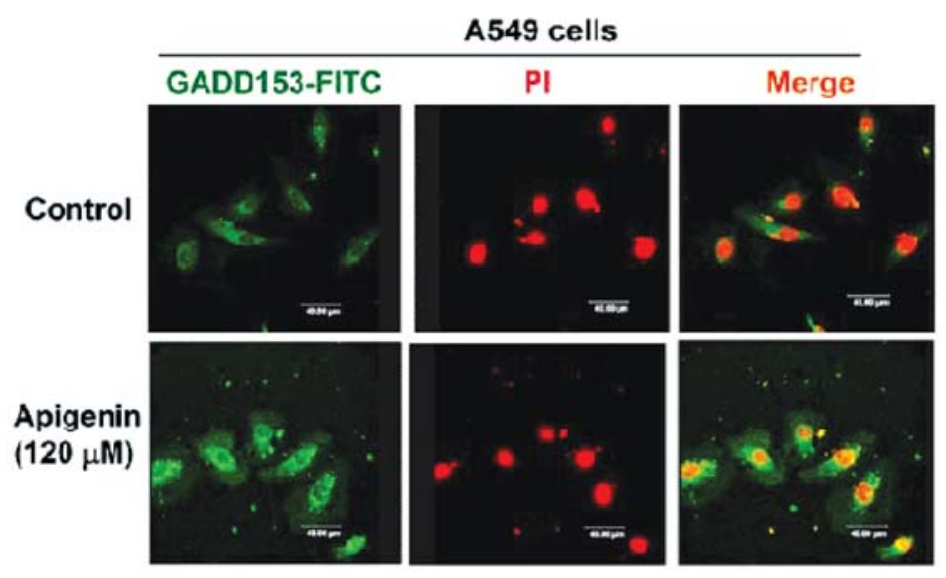

Figure 5. Apigenin affects AIF, Endo G and GADD153 distribution in A549 cells. Cells were incubated with $120 \mu$ M of apigenin $24 \mathrm{~h}$. Cells were fixed and stained with primary antibodies to AIF (A), Endo G (B) and GADD153 (C) FITC-labeled secondary antibodies were used (green fluorescence) and the proteins were detected by a confocal laser microscopic system. The nuclei were stained by PI (red fluorescence). Areas of colocalization between AIF, Endo-G and/or GADD153 expressions and cytoplasm and nuclei in the merged panels are yellow. Scale bar, $50 \mu \mathrm{m}$.

Endo $\mathrm{G}$ release from mitochondria before translocating to the nuclei.

In the present study, our results indicated that apigenin treatment in A549 cells led to a decrease in the level of $\Delta \Psi_{\mathrm{m}}$, induced cytochrome c, AIF and Endo G release from mitochondria before causing apoptosis. Furthermore, the increase in cytochrome c paralleled Apaf-1 levels observed between 6 and $24 \mathrm{~h}$ of apigenin exposure, which led to the activation of caspase- 3 causing apoptosis (Fig. 4C). In addition, we also observed a decrease in precaspase- 8 , albeit at higher doses of apigenin treatment. Furthermore, apigenin induced ER stress based on the observations of $\mathrm{Ca}^{2+}$ release and Grp78 and GADD153 expressions (Fig. 5B and C). Apparently, ER stress is due to the ROS production in A549 cells (Fig. 3A).

In our in vitro studies, growth inhibition and apoptosis induction of A549 cells by apigenin were observed at 80$160 \mu \mathrm{M}$ concentrations, which clearly provided mechanistic insights; however, these effects are also needed in vivo for potential clinical development in the future. It is of interest 


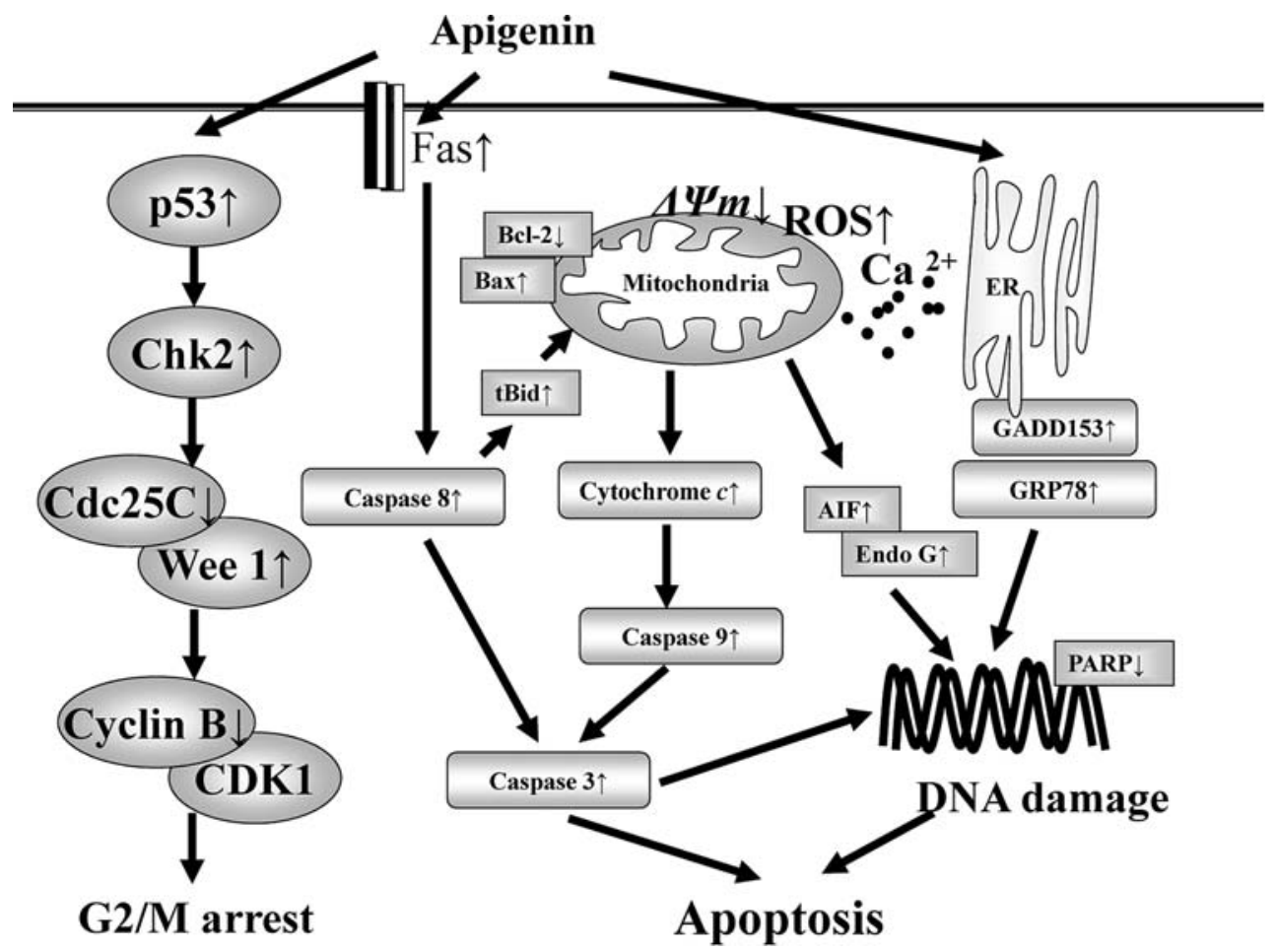

Figure 6. The proposed mechanisms and signaling pathways of apigenin-induced apoptosis in A549 cells.

that other investigators have demonstrated that using 20 and $50 \mu \mathrm{g}$ /day apigenin administration on mice with prostate cancer xenografts confirmed that apigenin administration significantly inhibited tumor growth, without any apparent signs of toxicity (19).

In conclusion, the possible signal pathways are summarized in Fig. 6 indicating that apigenin induces apoptosis in A549 cells through ROS production, ER stress, and is mitochondria-dependent. Understanding the modes of action of apigenin should provide information for lung cancer prevention in the future.

\section{Acknowledgments}

This work was supported by Grant CMU97-086 and CMU97087 from China Medical University.

\section{References}

1. Emami B, Graham MV and Purdy JA: Three-dimensional conformal radiotherapy in bronchogenic carcinoma: considerations for implementation. Lung Cancer 11 (Suppl. 3): S117-S128, 1994.

2. Hashibe M, Brennan P, Benhamou S, Castellsague X, Chen C, Curado MP, Dal Maso L, Daudt AW, Fabianova E, Fernandez L, Wunsch-Filho V, Franceschi S, Hayes RB, Herrero R, Koifman S, La Vecchia C, Lazarus P, Levi F, Mates D, Matos E, Menezes A, Muscat J, Eluf-Neto J, Olshan AF, Rudnai P, Schwartz SM, Smith E, Sturgis EM, Szeszenia-Dabrowska N, Talamini R, Wei Q, Winn DM, Zaridze D, Zatonski W, Zhang ZF, Berthiller J and Boffetta P: Alcohol drinking in never users of tobacco, cigarette smoking in never drinkers, and the risk of head and neck cancer: pooled analysis in the International Head and Neck Cancer Epidemiology Consortium. J Natl Cancer Inst 99: 777-789, 2007.

3. Parkin DM, Pisani P and Ferlay J: Estimates of the worldwide incidence of 25 major cancers in 1990. Int J Cancer 80: 827-841, 1999.
4. Rahman M, Sakamoto J and Fukui T: Calculation of population attributable risk for bidi smoking and oral cancer in south Asia. Prev Med 40: 510-514, 2005.

5. Meyskens FL Jr and Szabo E: Diet and cancer: the disconnect between epidemiology and randomized clinical trials. Cancer Epidemiol Biomarkers Prev 14: 1366-1369, 2005.

6. Steinmetz KA and Potter JD: Vegetables, fruit, and cancer. I. Epidemiology. Cancer Causes Control 2: 325-357, 1991.

7. Room R, Babor T and Rehm J: Alcohol and public health. Lancet 365: 519-530, 2005.

8. Balaram P, Sridhar H, Rajkumar T, Vaccarella S, Herrero R, Nandakumar A, Ravichandran K, Ramdas K, Sankaranarayanan R, Gajalakshmi V, Munoz N and Franceschi S: Oral cancer in southern India: the influence of smoking, drinking, paanchewing and oral hygiene. Int J Cancer 98: 440-445, 2002.

9. Patel D, Shukla S and Gupta S: Apigenin and cancer chemoprevention: progress, potential and promise (review). Int J Oncol 30: 233-245, 2007.

10. Ren W, Qiao Z, Wang H, Zhu L and Zhang L: Flavonoids: promising anticancer agents. Med Res Rev 23: 519-534, 2003.

11. Wei H, Tye L, Bresnick E and Birt DF: Inhibitory effect of apigenin, a plant flavonoid, on epidermal ornithine decarboxylase and skin tumor promotion in mice. Cancer Res 50: 499-502, 1990.

12. Tatsuta A, Iishi H, Baba M, Yano H, Murata K, Mukai M and Akedo H: Suppression by apigenin of peritoneal metastasis of intestinal adenocarcinomas induced by azoxymethane in Wistar rats. Clin Exp Metastasis 18: 657-662, 2000.

13. Liu LZ, Fang J, Zhou Q, Hu X, Shi X and Jiang BH: Apigenin inhibits expression of vascular endothelial growth factor and angiogenesis in human lung cancer cells: implication of chemoprevention of lung cancer. Mol Pharmacol 68: 635-643, 2005.

14. Fang J, Xia C, Cao Z, Zheng JZ, Reed E and Jiang BH: Apigenin inhibits VEGF and HIF-1 expression via PI3K/AKT/p70S6K1 and HDM2/p53 pathways. FASEB J 19: 342-353, 2005.

15. Trochon V, Blot E, Cymbalista F, Engelmann C, Tang RP, Thomaidis A, Vasse M, Soria J, Lu H and Soria C: Apigenin inhibits endothelial-cell proliferation in $\mathrm{G}(2) / \mathrm{M}$ phase whereas it stimulates smooth-muscle cells by inhibiting P21 and P27 expression. Int J Cancer 85: 691-696, 2000.

16. Schindler R and Mentlein R: Flavonoids and vitamin E reduce the release of the angiogenic peptide vascular endothelial growth factor from human tumor cells. J Nutr 136: 1477-1482, 2006. 
17. Shukla S and Gupta S: Suppression of constitutive and tumor necrosis factor alpha-induced nuclear factor (NF)-kappaB activation and induction of apoptosis by apigenin in human prostate carcinoma PC-3 cells: correlation with down-regulation of NF-kappaB-responsive genes. Clin Cancer Res 10: 3169-3178, 2004.

18. Shukla S, Mishra A, Fu P, MacLennan GT, Resnick MI and Gupta S: Up-regulation of insulin-like growth factor binding protein-3 by apigenin leads to growth inhibition and apoptosis of 22Rv1 xenograft in athymic nude mice. FASEB J 19: 2042-2044, 2005.

19. Shukla S and Gupta S: Molecular targets for apigenin-induced cell cycle arrest and apoptosis in prostate cancer cell xenograft. Mol Cancer Ther 5: 843-852, 2006.

20. Shukla S and Gupta S: Apigenin-induced prostate cancer cell death is initiated by reactive oxygen species and p53 activation. Free Radic Biol Med 44: 1833-1845, 2008.

21. Hsia TC, Yang JS, Chen GW, Chiu TH, Lu HF, Yang MD, Yu FS, Liu KC, Lai KC, Lin CC and Chung JG: The roles of endoplasmic reticulum stress and $\mathrm{Ca}^{2+}$ on rhein-induced apoptosis in A-549 human lung cancer cells. Anticancer Res 29: 309-318, 2009.

22. Yang JS, Chen GW, Hsia TC, Ho HC, Ho CC, Lin MW, Lin SS, Yeh RD, Ip SW, Lu HF and Chung JG: Diallyl disulfide induces apoptosis in human colon cancer cell line (COLO 205) through the induction of reactive oxygen species, endoplasmic reticulum stress, caspases casade and mitochondrial-dependent pathways. Food Chem Toxicol 47: 171-179, 2009.

23. Wei MC, Lindsten T, Mootha VK, Weiler S, Gross A, Ashiya M, Thompson CB and Korsmeyer SJ: tBID, a membrane-targeted death ligand, oligomerizes BAK to release cytochrome $\mathrm{c}$. Genes Dev 14: 2060-2071, 2000

24. Lu HF, Chen YS, Yang JS, Chen JC, Lu KW, Chiu TH, Liu KC, Yeh CC, Chen GW, Lin HJ and Chung JG: Gypenosides induced G0/G1 arrest via inhibition of cyclin $\mathrm{E}$ and induction of apoptosis via activation of caspases-3 and -9 in human lung cancer A-549 cells. In Vivo 22: 215-221, 2008.
25. Lin YT, Yang JS, Lin HJ, Tan TW, Tang NY, Chaing JH, Chang YH, Lu HF and Chung JG: Baicalein induces apoptosis in SCC-4 human tongue cancer cells via a $\mathrm{Ca}^{2+}$-dependent mitochondrial pathway. In Vivo 21: 1053-1058, 2007.

26. Shukla $S$ and Gupta S: Apigenin-induced cell cycle arrest is mediated by modulation of MAPK, PI3K-Akt, and loss of cyclin D1 associated retinoblastoma dephosphorylation in human prostate cancer cells. Cell Cycle 6: 1102-1114, 2007.

27. Hirpara JL, Clement MV and Pervaiz S: Intracellular acidification triggered by mitochondrial-derived hydrogen peroxide is an effector mechanism for drug-induced apoptosis in tumor cells. J Biol Chem 276: 514-521, 2001.

28. Trachootham D, Zhou Y, Zhang H, Demizu Y, Chen Z, Pelicano H, Chiao PJ, Achanta G, Arlinghaus RB, Liu J and Huang P: Selective killing of oncogenically transformed cells through a ROS-mediated mechanism by beta-phenylethyl isothiocyanate. Cancer Cell 10: 241-252, 2006.

29. Singh SV, Srivastava SK, Choi S, Lew KL, Antosiewicz J, Xiao D, Zeng Y, Watkins SC, Johnson CS, Trump DL, Lee YJ, Xiao $\mathrm{H}$ and Herman-Antosiewicz A: Sulforaphane-induced cell death in human prostate cancer cells is initiated by reactive oxygen species. J Biol Chem 280: 19911-19924, 2005.

30. Dini L: Apoptosis induction in DU-145 human prostate carcinoma cells. Tissue Cell 37: 379-384, 2005.

31. Bai J, Rodriguez AM, Melendez JA and Cederbaum AI: Overexpression of catalase in cytosolic or mitochondrial compartment protects HepG2 cells against oxidative injury. J Biol Chem 274: 26217-26224, 1999.

32. Robertson JD and Orrenius S: Molecular mechanisms of apoptosis induced by cytotoxic chemicals. Crit Rev Toxicol 30: 609-627, 2000.

33. Zou H, Li Y, Liu X and Wang X: An APAF-1.cytochrome c multimeric complex is a functional apoptosome that activates procaspase-9. J Biol Chem 274: 11549-11556, 1999.

34. Kim J and Soh J: Cadmium-induced apoptosis is mediated by the translocation of AIF to the nucleus in rat testes. Toxicol Lett 188: 45-51, 2009. 